\title{
PERTANGGUNG JAWABAN PRODUK (PRODUCT LIABILITY) SEBAGAI SALAH SATU ALTERNATIF PERLINDUNGAN KONSUMEN
}

Oleh:

\section{Liya Sukma}

\begin{abstract}
Law No 8 of 1999 on Consumer Protection regulate product liability as a kind of form liability of businesses man in terms of compensation for the damage, pollution and consumer loss due to the consumption of either produced or traded goods. Burden of proof to denote elements of faults exist or not is hold by businesses man. Main issue of this research is to know how producers liability on its products to consumers. Meanwhile, this research goal is to seek application of liability product principle to protect consumer from harms made by businesses man. This research used juridical-normative methodology with descriptive analysis.
\end{abstract}

\section{Keywords: Liability, Product, Consumer}

\section{PENDAHULUAN}

Perhatian terhadap perlindungan konsumen sangat diperlukan mengingat setiap orang, pada suatu waktu, apakah sendiri maupun kelompok bersama orang lain, dalam keadaan apapun pasti menjadi konsumen untuk suatu produk barang atau jasa tertentu. Oleh karena itu dengan diundangkannya Undang-Undang Nomor 8 Tahun 1999 tentang Perlindungan Konsumen ( UUPK) merupakan upaya pemberdayaan dalam rangka perlindungan konsumen. Dengan adanya UUPK kecenderungan kewajiban berhati-hati pada pembeli ( caveat emptor) mulai diarahkan sebaliknya kepada pelaku usaha yang perlu hati-hati (caveat venditor). ${ }^{1}$

Ada tiga hal yang perlu dicatat sehubungan dengan tanggung jawab

\footnotetext{
${ }^{1}$ Sidarta, Hukum Perlindungan Konsumen Indonesia,
} Jakarta: Grasindo, 2004, hlm. 50 produsen yaitu berdaya saing tinggi, barang yang makin bermutu dan bernilai tambah yang tinggi. Ketiga hal ini berkaitan dengan masalah tanggung jawaban produsen, karena adanya kesadaran dari para produsen terhadap tanggung jawabnya secara hukum akan berakibat pada adanya sikap penuhi kehati-hatian (precision), baik dalam menjaga kualitas produk, penggunaan bahan, maupun dalam kehati-hatian kerja. Tidak adanya atau kurangnya kesadaran akan tanggung jawabnya sebagai produsen akan berakibat fatal dan menghadapi resiko bagi kelangsungan hidup/kredibilitas usahanya. ${ }^{2}$ Rendahnya kualitas produk atau adanya cacat (defect) pada produk yang dipasarkan sehingga menyebabkan kerugian bagi konsumen, disamping akan

\footnotetext{
${ }^{2}$ E. Saefullah, Tanggung Jawab Produen (Product Liability) dalam Era Perdagangan Bebas (Hukum Perlindungan Konsumen), Bandung: Mandar Maju, 2000, hlm. 42.
} 
menghadapi tuntutan konpensasi (ganti rugi) juga akan berakibat bahwa produk tersebut akan kalah bersaing dalam merebut pasar.

Suatu perkembangan baru dalam masyarakat dewasa ini, khususnya di negara-negara maju, adalah makin nmeningkatkan perhatian terhadap masalah perlindungan konsumen. Apabila di masamasa yang lalu pihak produsen atau industriawan yang dipandang sangat berjasa bagi perkembangan perekonomian negara mendapat perhatian lebih besar, maka dewasa ini perlindungan terhadap konsumen lebih mendapat perhatian sesuai dengan meningkatnya perlindungan terhadap hakhak asasi manusia. Pihak konsumen yang dipandang lebih lemah perlu mendapatkan perlindungan hukum lebih besar dibandingkan masa-masa yang lalu. ${ }^{3}$

Product liability telah menarik perhatian yang meningkat dari berbagai kalangan, baik kalangan industri, konsumen, pedagang, industri asuransi, pemerintah, dan para ahli hukum. Namun demikian, hukum tentang product liability yang berlaku disetiap negara berbeda-beda. Dengan makin berkembangnya perdagangan internasional, maka permasalahan proaduct liability pun menjadi masalah yang melampaui batas-batas negara. Sehubungan dengan itu di berbagai negara, khususnya di negara-negara maju dan di dunia internasional telah dilakukan pembaharuanpembaharuan hukum yang berkaitan dengan product liability terutama dalam rangka mempermudah pemberian konpensasi bagi

3 Yuyut Prayuti, "Penerapan Doktrin Product Liability sebagai asas Pertanggung Jawaban Produsen dalam Perlindungan Konsumen", Tridharma. Majalah Ilmiah Kopertis Wilayah IV. Tahun XXIII,Nomor 10, Mei 2011. Hlm. 9. konsumen yang menderita kerugian akibat produk yang diedarkan di masyarakat.

Dalam mengantisipasi produk-produk barang atau jasa yang merugikan atau mencelakakan konsumen, sebagai negara peserta perdagangan bebas telah mengintroduksi doktrin product liability dalam tata hukumnya seperti Jepang, Inggris, Belanda, Amerika Serikat, dan Masyarakat Ekonomi Eropa serta negaranegara lain yang sudah terbiasa menjadikan hukum sebagai alat rekayasa sosial menuju kepastian hukum yang berkeadilan sosial.Realitas penegakan hukum menujukkan bahwa secara sadar atau tidak disadari, hukum melegitimasi ketidakadilan sosial ekonomi, misalnya struktur hukum sangat memungkinkan pengusaha/produsen menindas konsumen sebagai salah satu pelaku ekonomi. ${ }^{4}$

Melalui doktrin ini, telah diharapkan adanya "deregulasi" doktrin perbuatan melawan hukum (Pasal 1365 KUHPerdata) dinegara-negara tersebut sehingga semakin menyeimbangkan kedudukan dan peran konsumen terhadap pengusaha, sekalipun salah satu asas negara hukum telah menegaskan bahwa setiap orang memiliki kedudukan yang sama/seimbang di mata hukum.

\section{PEMBAHASAN}

Istilah product liability baru dikenal sejak sekitar 60 tahun yang lalu, yaitu dalam dunia perasuransian di Amerika Serikat sehubungan dengan dimulainya produk bahan makanan secara besar-besaran. Baik dikalangan produsen, maupun penjual

\footnotetext{
4 Yusuf Shofi, Perlindungan Konsemen dan Instrumen-Instrumen Hukumnya. Bandung: Citra Adhitya Bakti, 2000, hlm. 248.
} 
mengasuransikan barang-barangnya terhadap kemungkinan adanya risiko akibat produk-produk yang cacat atau menimbulkan kerugian terhadap para konsumen. Perkembangan selanjutnya adalah terjadinya penggabungan antara suatu jaminan dengan suatu janji yang sejak abad ke 19 telah ketentuan, bahwa penjual bertanggung jawab atas semua kerugian akibat adanya pelanggaran atas jaminannya. Namun disamping itu ada juga kecenderungan yang mengurangi hak-hak pembeli barang dengan adanya ketentuan yang mensyaratkan dengan suatu jaminan. Puncak perkembangan terakhir ini adalah sebagaimana dinyatakan dalam kasus Heilbut, Symsons \& Co. V. Buckleton, bahwa suatu pernyataan tidak dianggap sebagai jaminan kecuali dibuat with intent to contract. ${ }^{5}$

Secara terminologi "product liability" masih tergolong baru dalam doktrin ilmu hukum di Indonesia.Ada yang menterjemahkannya sebagai "tanggung Gugat produk".6 Pasal 19 UUPK menyatakan bahwa :

"Pelaku usaha bertanggung jawab memberikan ganti rugi atas kerusakan,pencemaran, dan/atau kerugian konsumen akibat mengkonsumsi barang dan/atau jasa yang dihasilkan atau diperdagangkan”.

Secara umum, tuntutan ganti kerugian atas kerugian yang dialami oleh konsumen sebagai akibat penggunaan produk, baik yang berupa kerugian materil, fisik,maupun

\footnotetext{
5 Erman Radjagukguk, et.al, Hukum Perlindungan Konsumen, Bandung: Mandar Maju, 2000, hlm. 210.

6 Agnes.M.Toar, dalam Shidarta, Hukum Perlindungan Konsumen Indonesia, Jakarta: Grasindo, 2004, hlm. 10.
}

jiwa, dapat didasarkan pada beberapa ketentuan yang telah disebutkan, yang secara garis besarnya hanya ada dua katagori, yaitu tuntutan ganti kerugian berdasarkan wanprestasi dan tuntutan ganti kerugian yang berdasarkan perbuatan melanggar hukum. ${ }^{7}$

Apabila tuntutan ganti kerugian didasarkan pada wanprestasi, maka terlebih dahulu tergugat dengan penggugat (produsen dan konsumen) terikat suatu perjanjian. Dengan demikian, pihak ketiga bukan sebagai pihak dalam perjanjian, yang dirugikan tidak dapat menuntut ganti kerugian dengan alasan wanprestasi.Ganti rugi yang diperoleh karena adanya wanprestasi merupakan akibat tidak dipenuhinya kewajiban utama atau kewajiban tambahan yang berupa kewajiban atas prestasi utama atau kewajiban jaminan/garansi dalam penjanjian.

Dalam tanggung gugat berdasarkan adanya wanprestasi, kewajiban untuk membayar ganti kerugian tidak lain dari pada akibat penerapan klausula dalam perjanjian, yang merupakan ketentuan hukum yang oleh kedua pihak secara sukarela tunduk berdasarkan perjanjiannya Dengan demikian, bukan undang-undang yang menentukan apakah harus dibayar ganti kerugian atau berapa besar ganti kerugian yang harus dibayar, melainkan kedua belah pihak yang menentukan syaratsyaratnyua serta besarnya ganti kerugian yang harus dibayar, dan apa yang telah diperjanjikan tersebut, mengikat sebagai undang-undang bagi mereka yang membuatnya.

\footnotetext{
7 Ahmad Miru \& Sutarman Yodo, Hukum Perlindungan Konsumen, Jakarta: Raja Grafindo Persada, 2004, hlm. 127.
} 
Berbeda dengan tuntutan kerugian yang didasarkan pada perikatan yang lahir dari perjanjian (karena wanprestasi), tuntutan ganti kerugian yang didasarkan pada perbuatan melanggar hukum tidak perlu didahului dengan perjanjian antara produsen dengan konsumen, sehingga tuntutan ganti kerugian dapat dilakukan oleh setiap pihak yang dirugikan walaupun tidak pernah terdapat hubungan perjanjian antara produsen dengan konsumen. Dengan demikian pihak ke tigapun dapat menuntut ganti rugi.Untuk menuntut ganti kerugian, maka kerugian tersebut harus merupakan akibat dari perbuatan melanggar hukum. Jika gugatan konsumen menggunakan kualifikasi perbuatan melawan hukum, hubungan kontraktual tidaklah disyaratkan. Dengan kualifikasi gugatan ini, konsumen sebagai penggugat harus membuktikan unsur-unsur :

1. Produsen telah melakukan perbuatan melawan hukum.

2. Produsen telah melakukan kesalahan.

3. Konsumen telah mengalami kerugian.

4. Kerugian yang dialami konsumen merupakan akibat hukum dari perbuatan melawan hukum yang dilakukan oleh produsen.

Jadi konsumen dihadapkan pada beban pembuktian berat, karena harus membuktikan keempat unusr tersebut. Hal ini dirasakan tidak adil bagi konsumen dengan dasar beberapa pertimbangan pertama, secara sosial ekonomi kedudukan konsumen lemah dibadingkan dengan kedudukan pengusaha/produsen, walaupun di mata hukum semua memiliki kedudukan yang sama. Dalam menghadapi gugatan konsumen, pengusaha lebih mudah mendapatkan pengacara untuk membela kepentingan-kepentingannya, termasuk dalam membuktikan dalil-dalilnya lewat keahlian para ahli dari berbagai bidang sesuai dengan produk yang dihasilkannya.

Bagi konsumen sulit membuktikan unsur ada tidaknya kesalahan/kelalaian produsen dalam proses produksi, pendistribusian dan penjualan barang atau jasa yang telah dikonsumsi konsumen. Di dalam berbagai kasus, termasuk kasus-kasus konsumen, yang dibuktikan adalah peristiwa-peristiwa positif dan peristiwa-peristiwa negatif. Menurut subekti, membuktikan peristiwaperistiwa negatif lebih sukar daripada membuktikan peristiwa-peristiwa positif. Hal ini dicontohkannya dalam hubungan antara pembeli dan penjual. Si pembeli dapat lebih mudah membuktikan bahwa ia sudah membayar daripada si penjual diminta membuktikan bahwa ia belum menerima pembayaran. ${ }^{8}$.

Dalam hubungan ini apabila konsumen harus membuktikan adanya kelalaian/kesalahan pengusaha dalam proses produksi barang/jasa maka sangat tidak adil, karena yang tahu proses produksinya adalah pengusaha yang bersangkutan. Karenanya pengusahalah yang harus membuktikan bahwa ia tidak lalai dalam proses produksinya. Untuk membuktikan unsur "tidak lalai" dalam proses produksinya, tentunya harus ada kriteria berdasarkan ketentuan hukum administrasi negara tentantang "Tata Cara Produksi yang Baik" yang dikeluarkan instasi/departemen yang berwenang. Dengan demikian penjelasan

\footnotetext{
8 Subekti, Hukum Perjanjian, Jakarta: Intermasa,
} 1979, hlm. 14. 
Subekti itu tidak berlaku umum untuk kasus-kasus konsumen, artinya sudah saatnya untuk mempertimbangkan dikedepankannya pembalikan beban pembuktian unsur kesalahan/kelalaian pada pihak produsen. Kedua, prinsip kesejajaran kedudukan produsen dengan konsumen tidak dengan sendirinya membawa konsekwensi konsumen harus membuktikan semua unsur perbuatan melawan hukum . Oleh karena itu terhadap doktrin perbuatan melawan hukum dalam perkara konsumen seyogyanya dilakukan "deregulasi" dengan menerapkan doktrin product liability kedalam doktrin perbuatan melawan hukum. Apalagi selama sekian ratus tahun, sistem hukum kita masih terbelenggu pada pola hubungan tradisional antara penjual dengan pembeli. Artinya terhadap produk cacat, penjuallah yang bertanggung jawab. Hal ini dapat dijumpai landasan hukumnya pada Pasal 1504 KUHPerdata yang menegaskan bahwa penjual betanggung jawab adanya "cacat tersembunyi" pada produk yang dijualnya. Karena karakter dasar product liability pada dasarnya adalah perbuatan melawan hukum.

Produk liabilty yang bertujuan melindungi konsumen meniadakan kewajiban konsumen untuk membuktikan kesalahan produsen, dan sebaliknya produsen berkewajiban membuktikan bahwa ia tidak melakukan kesalahan, konsekwensi logis dari kontruksi hukum, bahwa produsen harus membuktikan bahwa ia tidak bersalah adalah bahwa produsen dengan dianggap telah melakukan kesalahan seketika setelah konsumen mengalami kerugian akibat menggunakan produknya

Perkembangan hukum dari product liability ditandai dengan perkembangan penting yaitu dengan diakuinya pembebanan tanggung jawab terhadap pihak produsen didasarkan atas adanya kontrak, sehingga dengan demikian ruang lingkupnya sangat terbatas, yaitu hanya timbul di antara pihakpihak yang mengadakan kontrak antara korban dan produsen barang yang cacat/rusak tersebut. Pihak lain yang juga menjadi korban dari produk yang cacat atau tidak aman itu tidak dilindungi.

Selanjutnya dalam perjalanan panjang gerakan perlindungan konsumen di dunia, dikenal 2 (dua) macam adagium caveat emptor (waspadalah konsumen) yang kemudian dikembangkan menjadi caveat venditor (waspadalah pelaku usaha). Perkembangan kedua caveat ini sangat erat kaitannya dengan strategi bisnis yang digunakan oleh pelaku usaha.Seperti layaknya perkembangan dunia yang berjalan dewasa ini membuat pejuang gerakan perlindungan konsumen memberi perhatian kembali pada waspadalah konsumen, berdampingan dengan waspadalah pelaku usaha. $^{9}$ Hal tersebut berkaitan dengan asasasas pertanggungjawaban hukum secara perdata dalam UUPK, yaitu salah satunya pertanggung jawaban produk (product libility). Product libility sebenarnya mengacu sebagai tanggung jawab produsen yang oleh Agnes M. Toar diartikan sebagai berikut : " Tanggung jawab para produsen untuk produk yang dibawanya kedalam peredaran yang menimbulkan atau menyebabkan kerugian karena cacat yang melekat pada produk tersebut" 10

\footnotetext{
9 Johanes Gunawan, "Tanggung Jawab Pelaku Usaha Menurut Undang-Undang Nomor 8 Tahun 1999 tentang Perlindungan Konsumen”, Jurnal Bisnis, Vol 1, 1999, hlm. 10

10 Ibid.
} 
Produk secara umum diartikan sebagai barang yang secara nyata dapat dilihat dan dapat dipegang (tangible goods), baik yang bergerak maupun tidak bergerak. Namun dalam kaitan dengan masalah product liability produk bukan hanya berupa tangible goods tapi juga termasuk yang bersifat intangible seperti listrik, produk alami (misal: makanan binatang piaran dengan jenis binatang lain), tulisan (misal: peta penerbangan yang diproduksi secara masal), atau perlengkapan tetap pada rumah real estate (misal rumah). ${ }^{11}$

Produk tersebut tidak semata-mata suatu produk yang sudah jadi secara keseluruhan, tapi juga termasuk komponen dan sukucadang. Berkenaan dengan masalah cacat/rusak (defect) dalam pengertian produk yang cacat/rusak (defective product) yang menyebabkan produsen harus bertanggung jawab, dikenal tiga macam produk yang cacat yaitu : kesalahan produk, kesalah produk ini dapat dibedakan atas dua bagian, yaitu pertama adalah kesalahan yang meliputi kegagalan proses produksi, pemasangan produk, kegagalan pada sarana inspeksi, apakah karena kelalaian manusia atau ketidakberesan pada mesin dan yang serupa dengan itu, sedangkan yang kedua adalah produk-produk yang telah sesuai dengan rancangan dan spesifikasi yang dimaksud oleh pembuat, namun terbukti tidak aman dalam pemakaian. Cacat desain. Pada cacat desain ini cacat terjadi pada tingkat persiapan produk. Hal ini terdiri dari atas, desain, komposisi, atau kontruksi, Informasi yang catat atau yang tidak memadai, informasi yang tidak memadai ini berhubungan dengan pemasaran suatu produk, dan dimana keamanan suatu produk

${ }^{11}$ E Saefullah, Op.Cit. hlm. 44. ditentukan oleh informasi yang diberikan kepada pemakai yang berupa pemberian label produk, cara penggunaan, peringatan atas risiko tertentu atau hal lainnya sehingga produsen pembuat dan supplier dapat memberikan jaminan bahwa produk-produk mereka itu dapat dipergunakan sebagaimana dimaksud. Dengan demikian produsen berkewajiban untuk memperhatikan keamanan produknya.

Product liability ini oleh banyak ahli dimasukan dalam sisitematika yang berbeda. Ada yang mengatakan product libility sebagai bagian dari hukum perikatan, hukum perbuatan melawan hukum, hukum kecelakaan, dan ada yang menyebutkannya sebagai bagian dari hukum konsumen. Pandangan yang lebih maju menyatakan product liability ini sebagai bagian hukum sendiri. ${ }^{12}$

Dasar gugatan untuk produk liability dapat dilakukan atas dasar adanya pelanggaran jaminan, kelalaian, dan tanggung jawab mutlak. Pelanggaran jaminan berkaitan dengan jaminan pelaku usaha (khusus produsen), bahwa barang yang dihasilkan atau dijual tidak mengandung cacat.Pengertian cacat bisa terjadi dalam kontruksi barang, desain, dan/atau pelabelan/informasi. Adapun yang dimaksud dengan kelalaian adalah bila pelaku usaha yang digugat itu gagal menunjukan, ia cukup berhati-hati, dalam membuat, menyimpan, mengawasi, memperbaiki, memasang label, atau pendistribusian suatu barang. Contoh kasus biskuit beracu (CV Gabico) yang terjadi di Indonesia tahun 1989, yang setidak-tidaknya telah menimbulkan korban 141 jiwa konsumen tak berdosa, 35 orang diantaranya

\footnotetext{
${ }^{12}$ Sidarta, Op Cit, hlm. 30.
} 
meninggul dunia. Hasil penyelidikan menyimpulkan bahwa amonium bicarbonat, yaitu sejenis bahan pembuat biskuit supaya renyah, telah tertukar dengan sodium nitrit, sejenis bahan berbahaya pada waktu pemindahan bahan-bahan tersebut.(Nota Keprihatinan Organisasi Konsumen se Indonesia atas Kasus Biscuit Beracun,1994). Tragedi ini terjadi pada beberapa tempat yang berbeda, antara lain Tangerang, Tegal, Pelembang, Jambi. Para korban tersebut tidak mendapatkan konpensasi dari pihak yang bertanggung jawab. Kalau saja pada waktu itu, tidak ada uluran tangan soedomo, menteri Koordinator Politik dan Keamanan (Menko Polkam) pada waktu itu, nasib para korban dan keluarganya menjadi semakin buruk. $^{13}$

Kasus yang menyangkut ketidakamanan pangan terulang kembali pada bulan Juni 1994 di Pelembang, Jambi, dan beberapa tempat laonnya, 28 orang dirawat di rumah sakit, 5 orang lainnya meninggal dunia. Hasil investigasi yang berwenang, antara lain menyalahkan konsumen, bahwa air dan alat yang digunakan tercemar. Dipertanyakan, jika yang tercemar air, mengapa yang menjadi korban hanya mereka yang mengkonsumsi mie instant, sedangkan yang tidak malah selamat. Menarik sekali sikap Pangdam II/Sriwijaya yang segera memerintahkan produsen mie instant untuk segera menarik kembali produknya dari pasaran sambil menunggu keputusan intrumen hukum adminstrasi negara, dalam hal ini Direktorat Jenderal Pengawasan Obat dan Makanan Departemen Kesehatan Republik Indonesia. Menurut pemantauan Yayasan Lembaga Konsumen Indonesia bersama organisasi konsumen

${ }^{13}$ Yusuf Shopie, Op.Cit. hlm. 257. daerah, pihak PT Indofood sebagai produsen mei instant memasang iklan besar-besar di beberapa harian utama Kompas, Suara Karya, Republika, Suara Pembaharuan pada Edisi minggu kedua Juli 1994. Isinya mengenai pengumuman penarikan produk yang kedaluarsa. Adanya pengumuman penarikan produk yang kedaluarsa ini, menunjukan adanya indikasi bahwa mekanisme pengawasan produk di pasaran tidak atau belum berjalan, baik oleh instansi Departemen Kesehatan maupun oleh quality control produsen yang bersangkutan.

Dengan memperhatikan lokasi tempat konsumen mengalami musibah, antara lain dengan membeli secara eceran di warung atau toko, rantai distribusi produk pada kedua kasus itu cukup luas jangkauan pasarannya, tanpa diimbangi dengan keamanan dan keselamatan konsumen yang memadai. Diduga kuat telah terjadi kelalaian/kesalahan di dalam proses produksi dan proses pemasaran/penjualan yang diakibatkan sangat fatal bagi konsumen.

Dalam Kasus mie instant tidak ada tindakan hukum yang diambil oleh aparat penegak hukum, kecuali sebatas desakan dari departemen kesehatan, kepolisian dan keamanan untuk menarik produk-produk yang kadaluarsa. Sebaliknya, pada kasus biskuit beracun, pengurus/karyawan CV Gabisco sebagai produsennya dijatuhi pidana 6 (enam) bulan penjara dengan masa percobaan 1 (satu) Tahun.(Ibrahim Idham dkk,1993). Sebetulnya putusan pengadilan ini, dalam hal ini pertimbangannya, dapat menjadi landmark decision, tetapi yang menjadi justru sebaliknya. Majelis hakim mengesampingkan Peratura Menteri Kesehatan Republik Indonesia (Permenkes) 
No. 23/Menkes/SK/I/1978 tentang Pedoman Cara Produksi yang baik untuk Makanan. Sebagaimana telah dikemukakan di atas, untuk menentukan ada tidaknya kelalaian dalam proses produksi atau peredaran suatu produk, maka harus ada kreteria/patokan tentang "Tata Cara Produksi yang Baik" dari instruksi hukum administrasi negara yang berwenang seperti Departemen Kesehatan.

Dalam pertimbangan majelis hakim menegaskan bahwa dakwaan Pasal 205 ayat (1) Kitab Undang-Undang Hukum Pidana (KUHP) karena kealfaannya menyebabkan barang-barang yang berbahaya dijual tanpa diketahui sifat berbahayanya oleh pembeli, sebagai dakwaan yang berdiri sendiri dengan mengesampingkan Permenkes tersebut. Apalagi majelis hakim menyatakan bahwa Permenkes itu tidak ada sanksinya bila dilanggar. Pertimbangan ini sama saja dengan menyatakan bahwa unsur utama dalam kaidah hukum adalah sanksi, padahal unsur utama dalam kaidah hukum adalah adanya patokan atau batasan terhadap perilaku-perilaku yang seyogianya dilakukan atau tidak dilakukan. Dalam 2 (dua) kasus tersebut. Patokan/ batasan perilaku di dalam proses produksi dari peredaran makanan sudah jelas. Sedangkan sanksi sendiri tidak menunjukan adanya patokan/batasan tersebut. Sanksi berperan menegakkan patokan/batasan perilaku sebagai kaidah.

Dalam Kasus biskuit beracun, pengadilan belum berani membuat terobosan product libility dalam pertimbangan putusannya. Harapan penyelesaian melalui pengadilan pada kasus mie instrant juga tidak kedengaran gaungnya.Inisiatif untuk melakukan gugatan perdata dari Yayasan Lembaga Konsumen
Indonesia (YLKI) dengan kualifikasi perbuatan melawan hukum tidak kunjung dilakukan. Padahal dengan menguji kedua landmark case tersebut, diharapkan muncul terobosan-terobosan baru dalam putusanputusan pengadilan, baik dalam pertimbangan maupun amar putusannya., menyangkut kasus konsumen, khususnya yang menyangkut keamanan dan keselamatan konsumen dalam mengkonsumsi produk barang dan jasa.

Dengan diaturnya doctrin product libility dalam tata hukum, perasaan hukum dan keadilan masyarakat menghendakinya lain, kiranya berdasarkan ketentuan di dalam UUPK yang mengatur tentang product linility menggunakan struktur pertanggungjawaban perdata. Dalam rangka harmonisasi hukum yang mengatur tentang product libility di kawasan perdagangan bebas, maka cenderung mengunggulkan penggunaan pertanggungjawaban langsung sebagai derivasi dari pertanggungjawaban berdasarkan kesalahan, karena pengalihan beban pembuktian unsur kesalahan dari konsumen kepada pelaku usaha merupakan salah satu upaya melindungi konsumen.

Sebagai suatu ilustrasi dapat dikemukakan sebuah contoh di negara maju yang dipaparkan oleh Paul Strom, member of the Rotterdam bar, sebagai berikut, Voctor Frespils, seorang supir truk, suatu hari pada musim panas menghadiri undangan sahabatnya. Dia mengambil botol bir dari self service bar dengan maksud untuk membukanya, dan ketika dia mengambil botol air memegang tutupnya tiba-tiba botol tersebut meledak dan menyebabkan luka parah pada mukanya. Setelah dilakukan operasi darurat diketahui bahwa matanya sebelah kiri menjadi buta 
sedangkan yang sebelah kanan mengalami cacat tetap. Akibatnya kecelakaan tersebut Victor kehilangan pekerjaannya untuk seumur hidupnya.

Tentu saja si pengundang merasa kaget dan segera menuntut pemilik toko yang menjual bir tersebut kepadanya. Pemilik toko menyatakan bahwa dia menyimpan botol-botol bir tersebut sesuai dengan aturan dan tidak diperlukan untuk memeriksanya satu persatu sebelum menjualnya. Dia merasa tidak dapat dipersalahkan, dan menunjuk agen sebagai pihak yang bertanggung jawab. Pihak agen juga mengemukakan alasan yang sama dan dia menujukan pabrik bir sebagai pihak yang harus bertanggung jawab. Setelah dilakukan penelitian yang seksama dari berbagai aspek dilingkungan pabriknya dan segala yang berkaitan sekitar terjadinya kecelakaan, maka disimpulkan bahwa pada bagian atas botol ternyata sangat tipis. Disamping itu diketahui juga bahwa botol-botol bir tersebut telah disimpan selama dua hari oleh si pengundang dan ditempatkan di gudang di samping rumahnya yang suhunya mencapai 30 derajat Celcius. Meledaknya botol tersebut sangat mungkin disebabkan oleh tipisnya dibagian atas botol khususnya karena tekanan suhu ditempat botol dibuka dan berprosesnya gas di dalam botol menyebabkan tekanan menjadi tinggi.Karena itu pabrik bir menunjuk pabrik botol dan orang yang mengundang persta yang seharusnya bertanggung jawab.

Sementara itu, Victor Freshpils menghitung kerugian yang dideritanya: biaya rumah sakit, kehilangan penghasilan yang bakal diterimanya selama lebih dari 30 tahun lagi, konpensasi untuk kesakitan dan penderitaan. Namun pertanyaannya, dapatkan dia menuntut dan kepada siapa ? jawaban yang paling mudah adalah menyerahkan kasus ini kepada pengacara yang baik. Tetapi setelah dia kehilangan pekerjaannya (dan mungkin juga sebelumnya) Victor tidak punya uang untuk membayar pengacara, biaya para saksi, dan para ahli indpenden untuk menyelidiki sebeb meledaklah botol bir tersebut.Belum lagi apabila kasusnya kalah di pengadilan. Andaikata Victor menyerahkan kasusnya kepada pengacara masalah yang sama yang dihadapi oleh si pengacara adalah kepada siapa tuntutan akan mulai diajukan ?. Apabila telah ditemukan siapa yang akan menjadi tergugat, pertanyaan berikutnya adalah menuntut untuk kerugian apa ?. Demikian juga masalah-masalah tepat kedudukan Victor, toko bir, agen, pabrik bir, dan pabrik botol. Seandainya Victor tinggal di Jerman, kecelakaan terjadi di Belanda, toko penjual bir berkantor pusat di Belanda, dan agen serta pabrik bir berkantor pusat di Belgia. Hukum mana yang berlaku ?. Pada saat ini sulit untuk menjawab secara tepat hukum mana yang akan berlaku, tergantu dari Hukum Perdata Internasional (HPI) yang akan diberlakukan oleh pengadilan dimana kasus diajukan. Di samping itu sebagimana diketahui dalam banyak kasus HPI tidak memberikan jawaban yang tegas, hanya dalam kebanyakan kasus kelihatannya lex loci delicti diberlakukan di sebagian besar negara.

Untuk mengatasi keadaan chaos demikian maka Hague Conference Private Internasional Law telah menyusun Convention on the Law Applicable to Product Liability, yang terbuka untuk penandatanganan sejak 2 October 1973. Dengan konvensi tersebut maka pihak 
konsumen yang dirugikan dipermudah dalam proses menuntut kerugian yang dideritanya.Sehubungan dengan itu maka menjadi penting adalah hukum yang berlaku di negara di mana kerugian terjadi, apakah cukup melindungi konsumen atau tidak. Dan untuk itu tergantung pada prinsip tanggung jawab atas dasar kesalahan (based on fault/negligence), atas dasar praduga (presumption of liability), atau prinsip tanggung jawab mutlak (strikct/absolute liability).

Product liability merupakan lembaga hukum yang relatif baru untuk Indonesia. Namun demikian UUPK telah menganut product libility yang menggunakan pertanggungjawaban mutlak sebagai deviasi dari pertanggungjawaban kesalahan disertai pengalihan beban pembuktian unsur kesalahan dari konsumen kepada pelaku usaha. Hal ini sejalan dengan tujuan perlindungan konsumen, baik secara nasional maupun secara regional di kawasan perdagangan bebas.

Diterapkannya product libility dalam UUPK terhadap para pelaku usaha yang memproduksi barang dan kemudian ternyata barang tersebut menimbulkan kerusakan, pemcemaran, dan/atau kerugian pada badan, jiwa dan barang milik konsumen, maka konsekuensi diterapkannya product libility pelaku usaha dapat dikenakan sanksi perdata berdasarkan Pasal 19 UUPK, pelaku usaha (hal ini produsen) yang produknya merugikan konsumen, harus memberikan ganti rugi, ganti rugi berupa pengembalian uang, penggantian barang yang sejenis atau yang setara nilainya, perawatan kesehatan, pemberian santunan yang sesuai dengan ketentuan peraturan perundang-undangan yang berlaku. Berhubung intisari dari product libility adalah pertanggungjawaban atas dasar perbuatan melawan hukum,maka keempat unsur di dalam pertanggungjawaban atas dasar perbuatan melawan hukum itu harus dibuktikan.

Dalam penerapan sanksi perdata tetap merupakan persyaratan untuk memperoleh ganti rugi dalam kasus product libility hanya pembuktian unsur kesalahan bukan beban konsumen lagi, melainkan merupakan beban produsen untuk membuktikan bahwa ia tidak bersalah (pembuktian tebalik). Hal ini ditetapkan dalam Pasal 28 UUPK yang menyatakan bahwa : "pembuktian terhadap ada atau tidaknya unsur kesalahan dalam gugatan ganti rugi dalam Pasal 19 UUPK merupakan beban dan tanggung jawab pelaku usaha (produsen). Disamping sanksi perdata UUPK mengatur juga sanksi pidana sebagaimana diatur dalam Pasal 62 ayat (1) dan ayat (2) UUPK, maka produsen yang melanggar ketentuan-ketentuan di atas dipidana dengan pidana penjara paling lama lima (5) tahun atau dua (2) tahun atau pidana denda paling banyak Rp 2.000.000.000,- ( 2 Miliar rupiah) atau Rp. 500.000.000,- (lima ratus juta rupiah), tergantung pasal mana yang dilanggarnya. Pelanggaran UUPK oleh pelaku usaha yang mengakibatkan konsumen mengalami luka berat, sakit berat, cacat tetap atau kematian, berdasarkan Pasal 62 ayat (3) UUPK dikenakan ketentuan pidana yang berlaku, antara lain ketentuan-ketentuan di dalam KUHP. Hal baru dalam pengaturan perlindungan konsumen yang diatur dalam UUPK adalah pembuktian terbalik dalam kasus pidana seperti yang diatur oleh Pasal 22 UUPK yang menyatakan bahwa:"pembuktian tehadap ada tidaknya unsur kesalahan dalam kasus pidana 
sebagimana dimaksud dalam Pasal 19 UUPK merupakan beban dan tanggungjawab pelaku usaha,tanpa menutup kemungkinan bagi jaksa untuk melakukan pembuktian.

\section{KESIMPULAN}

Pasal 19 UUPK yang mengatur tentang product libility ini, yang menyatakan bahwa pelaku usaha bertanggung jawab memberikan ganti rugi atas kerusakan, pencemaran, kerugian konsumen akibat mengkonsumsi barang yang dihasilkan atau diperdagangkan. Product libility yang bertujuan melindungi konsumen, karena produsen telah melakukan kesalahan seketika setelah konsumen mengalami kerugian akibat menggunakan produknya.

\section{DAFTAR PUSTAKA}

\section{Buku dan Karya Ilmiah}

Ahmadi Miru \& Sutarman Yodo, Hukum Perlindungan Konsumen,Jakarta: Raja Grafindo Persada, 2004.

Erman Radjagukguk, et.al, Hukum Perlindungan Konsumen, Bandung: Mandar Maju, 2000.

E.Saefullah, Tanggung Jawab Produsen (Product Liability) dalam Era Perdagangan Bebas. (Hukum Perlindungan Konsumen), Bandung: Mandar Maju, 2000.

Johannes Gunawan, “Tanggung Jawab Pelaku Usaha Menurut UndangUndang Nomor 8 Tahun 1999 tentang Perlindungan Konsumen", Jurnal Bisnis, Vol 1.1999.
Hukum perlindungan

Konsumen, Bandung: Universitas

Katolik Parahyangan Program Pancasarjana Program Magister Ilmu Hukum.

Sidarta, Hukum Perlindungan Konsumen Indonesia, Jakarta: Grasindo, 2004.

Subekti, Hukum Perjanjian, Jakarta: Internusa, 1979.

Sudargo Gautama, Capita Selecta Hukum Perdata Internasional, Bandung: Alumni. 1998.

Yusuf Shopie, Perlindungan Konsumen dan Instrumen-Instrumen Hukumnya, Bandung: Citra Aditya Bakti, 2000.

Yuyut Prayuti, "Penerapan Doktrin Product Liability sebagai Asas Pertanggungjawaban Produsen dalam Perlindungan Konsumen. Tridharma", Majalah Ilmiah Kopertis Wilayah IV. Tahun XXIII, Nomor 10, Mei 2011.

\section{Perundang-undangan}

Undang-Undang Nomor 8 Tahun 1999 tentang Perlindungan Konsumen. 